Article

\title{
Planning for Exclusion: The Politics of Urban Disaster Governance
}

\author{
Ricardo Fuentealba *, Hebe Verrest and Joyeeta Gupta \\ Department of Human Geography, Planning and International Development, Amsterdam Institute for Social Science \\ Research, University of Amsterdam, 1018 WV Amsterdam, The Netherlands; E-Mails: r.fuentealba@uva.nl (R.F.), \\ h.j.I.m.verrest@uva.nl (H.V.), j.gupta@uva.nl (J.G.) \\ * Corresponding author
}

Submitted: 14 April 2020 | Accepted: 22 May 2020 | Published: 10 December 2020

\begin{abstract}
Many disaster risk reduction (DRR) initiatives, including land use planning, tend to ignore existing long-term inequalities in urban space. Furthermore, scholars working on urban disaster governance do not adequately consider how day-to-day DRR governing practices can (re)produce these. Hence, following a recent interest in the political dimensions of disaster governance, this article explores under what conditions the implementation of DRR land uses (re)produce spatial injustice on the ground. We develop a theoretical framework combining politics, disaster risk, and space, and apply it to a case study in Santiago, Chile. There, after a landslide disaster in the city's foothills in 1993, a multi-level planning arrangement implemented a buffer zone along the bank of a ravine to protect this area from future disasters. This buffer zone, however, transformed a long-term established neighbourhood, splitting it into a formal and an informal area remaining to this day. Using qualitative data and spatial analysis, we describe the emergence, practices, and effects of this land use. While this spatial intervention has proactively protected the area, it has produced further urban exclusion and spatial deterioration, and reproduced disaster risks for the informal households within the buffer zone. We explain this as resulting from a governance arrangement that emerged from a depoliticised environment, enforcing rules unevenly, and lacking capacities and unclear responsibilities, all of which could render DRR initiatives to be both spatially unjust and ineffective. We conclude that sustainable and inclusive cities require paying more attention to the implementation practices of DRR initiatives and their relation to long-term inequities.
\end{abstract}

\section{Keywords}

Chile; disaster risk reduction; land use planning; post-disaster; spatial injustice; urban disaster; urban governance

\section{Issue}

This article is part of the issue "The Politics of Disaster Governance" edited by Dorothea Hilhorst (Erasmus University Rotterdam, The Netherlands), Kees Boersma (Vrije Universiteit Amsterdam, The Netherlands) and Emmanuel Raju (University of Copenhagen, Denmark).

(C) 2020 by the authors; licensee Cogitatio (Lisbon, Portugal). This article is licensed under a Creative Commons Attribution 4.0 International License (CC BY).

\section{Introduction}

Cities are important sites for realising climate change adaptation and disaster risk reduction (DRR). This requires urban governance to move away from statecentric, top-down approaches towards more horizontal and coordinated work with communities and relevant actors. Research on factors contributing to 'good governance' of disaster risk highlights the need for cities to reduce vulnerability and hazard exposure while enhancing democratic and effective protection (e.g., Ahrens \& Rudolph, 2006; Gall, Cutter, \& Nguyen, 2014; United Nations Office for Disaster Risk Reduction, 2020). However, while urban disaster governance can promote sustainable and resilient development, achieving such goals in practice is complex. Normative and technocratic approaches do not adequately address the political dimensions of city governance (Swyngedouw, 2005; Tierney, 2012). Academic research increasingly focuses on decentralisation and scale (Marks \& Lebel, 
2016; Rumbach, 2016), accountability (Raju \& da Costa, 2018), informality (Parthasarathy, 2015), community participation (Pelling, 2011), networks and co-governance (Srikandini, van Voorst, \& Hilhorst, 2018), urbanisation trends (Miller \& Douglass, 2016), and vulnerability (Sandoval \& Voss, 2016). These works emphasize how institutions, socio-political relations, and discourses are coordinated and mediated in city contexts (Marks, 2015; Wamsler, 2006).

We aim to contribute to this literature on the politics of disaster governance by analysing the practices involved in land use planning as a particular instrument for reducing risks in cities. Land use management has been regarded as a more effective systemic and integrated way of dealing with hazards, in comparison to using singular instruments such as warning systems, relief and insurance, or structural measures (Burby, 1998). The basic notion in this context is that, "rather than trying to keep the flood out of people's way, government [should work] to keep people out of the flood's way by discouraging development of hazardous areas" (Burby, 1998, p. 9). Land use planning for DRR includes zoning regulations, building codes, flood-proof requirements, the acquisition and transformation of land, and/or information regarding design techniques (Burby, Deyle, Godschalk, \& Olshansky, 2000; Godschalk, 2003). It holds a crucial opportunity for managing risks in cities and, being embedded in the wider functioning of the urban system, involves a number of governance innovations (Asian Development Bank, 2016).

However, all such interventions will have winners and losers: "Land use planning, while superficially a technical act, is more often a reflection (not to say tool of) the dominant interests in a city and their vision for its future" (Pelling, 2011, p. 384). Evidence shows that many well-meaning land use planning approaches produce unintended, ambivalent, and unjust results in space (Sandoval, Gonzalez-Muzzio, \& Albornoz, 2017). Land use planning can negatively affect already disadvantaged groups and "protect economically valuable areas over low-income or minority neighbourhoods" (Anguelovski et al., 2016, p. 334); adopting a coastal buffer zone produced socio-economic disparities, livelihoods lost, and ecosystem damages in post-disaster Sri Lanka (Ingram, Franco, Rio, \& Khazai, 2006); the selective application of high-risk zones in Manilla in the name of resilience has led to evictions (Alvarez \& Cardenas, 2019). Disaster governance can exacerbate vulnerability by (re)creating some 'unsafe conditions' (Sandoval \& Voss, 2016). Although the literature asserts that DRRlike all policy interventions-is a political process, there is still a need to expand this knowledge in terms of how DRR governance evolves over time and how and when policy implementation produces certain effects on the ground. Clearly, post-disaster politics is very complex (Ingram et al., 2006; Pelling \& Dill, 2010). Hence, this article asks: Under what conditions does the implementation of land use planning for DRR produce and/or re- produce spatial injustice on the ground? We answer this question using an urban disaster governance framework and apply it to a case study in Chile where, following a landslide disaster in 1993 in the foothills of Santiago, the authorities developed a disaster risk management plan including a buffer zone in order to reduce the risks of future landslides.

This article first presents a conceptual discussion of urban disaster governance, then the research design, followed by our findings, and a discussion and conclusion section.

\section{The Politics of Urban Disaster Governance: A Conceptual Framework}

Our framework combines the politics of governance with critical understandings of disaster risks and urban space, and aims to develop a situated analysis of urban disaster governance. The politics of governance refers to how different actors network, participate, and collaborate to solve their own problems (Bevir, 2013; Gupta, Verrest, \& Jaffe, 2015; Torfing, Peters, Pierre, \& Sorensen, 2012). While a normative understanding of governance focuses on what constitutes 'good governance' and calls for legitimacy, accountability, equity, efficiency, and other such principles, this is critiqued for being implemented technocratically, obscuring political dimensions, and prioritizing efficiency over equity. As such, it may actually undermine democratic principles (Swyngedouw, 2005) and oversimplify complex social processes, resulting in "policies [that] often do not fully achieve the envisaged objectives and regularly have unintended consequences" (Di Baldassarre, Kemerink, Kooy, \& Brandimarte, 2014, p. 136). On the contrary, an analytical perspective on governance considers it as inherently political, encompassing differences, contestations, and power-laden decisions (Castán Broto, 2017; Gupta et al., 2015). For urban disasters, these include contesting visions of governing cities and their consequences for producing vulnerability and hazard exposure, as well as how power influences actor relations and shapes institutions, particularly in a context of decentralising fiscal and political competencies. For example, an 'incomplete decentralisation' in Thailand led to a transfer of mandates without accompanying resources to lower governments which unevenly increased flood risks (Marks \& Lebel, 2016). Hence, there is a need to unpack the inherent power relations between actors in existing horizontal and vertical arrangements.

We focus here on everyday practices of governance as a fruitful way for understanding the politics of policy design and implementation (Cornea, Véron, \& Zimmer, 2017). Such governance processes involve continuing negotiation and adaptation of norms and plans, and in these negotiations, issues may be technocratised by those with power (Ferguson, 1994). The "bias in disaster governance research" also privileges a focus on state-based processes over bottom-up and informal engagements (Huang, 2018, p. 384). Therefore, focusing 
on everyday practices helps to understand the informal and open-ended nature of certain formal structures in space (Koster \& Nuijten, 2016; McFarlane, 2012; Roy, 2005; Yiftachel, 2009), such as disaster risks and informality (Parthasarathy, 2015) or coastal resilience planning (Weinstein, Rumbach, \& Sinha, 2019), and exposes the unintended effects arising from (de)politicised settings (Marks, 2015). However, it should clearly not lead to an abdication of state responsibility.

We link urban politics, disaster risks, and injustice. Urban problems (e.g., inequalities, exclusions) do not just reflect governance failures, but arise from how governance systems work as results of socio-spatial processes of stratification that represent particular (in)justices (Harvey, 1973; Soja, 2010). Such problems are exacerbated during disasters, understood not as natural but deeply social and contentious phenomena that can increase marginalisation (Susman, O'Keefe, \& Wisner, 1983) and vulnerability (Wisner, Blaikie, Cannon, \& Davis, 2004), calling for a focus on root causes (Oliver-Smith, Alcántara-Ayala, Burton, \& Lavell, 2017) and disaster justice (Douglass \& Miller, 2018; Huang, 2018; Nygren, 2018). We argue that analysing spatial (in)justices is not only about describing the end state of social groups in space, but also about the relational and multilevel structural processes that put some people in marginal positions (Wacquant, 2015). Hence, we focus on "how, and where, power is being exercised, to whose benefit, and how it leads to urban development where risk is unequally distributed" (Rumbach, 2017, p. 784). Locating spatial injustices thus entails expanding on the distributional, procedural, and recognitional dimensions of justice as exerted and produced by situated practices of governance.

We integrate the above in a conceptual framework presented in Figure 1, which visualises the need to mediate land use planning and its multi-level implementation arrangements through what we call their everyday governing practices. By addressing the interaction of these practices with grounded actors, that is, how planning interfaces with communities on the ground, we can further understand the ambivalent consequences of positive DRR outcomes along with the socio-spatial (in)justices that emerge. Ultimately, this can help to address the process of implementation and outcomes of land use planning that make DRR not only ineffective but also unjust.

\section{Research Design}

We combined qualitative and spatial methods for understanding the implementation of a land use plan in Chile. We conducted six months of fieldwork focused on an area of the foothills of Santiago (see Figure 2), characterised by steep slopes and hazardous hydro-geological formations (Muñoz, 1990; Sepúlveda, Rebolledo, \& Vargas, 2006). We gained access through a long-term resident of the foothills and later followed a snow-balling process for identifying and contacting key informants. We conducted 48 in-depth anonymised interviews that included: members of the local communities and residents with experience in planning initiatives; municipal representatives working on urban and emergency planning; politicians and representatives of national institutions; and experts in Chilean urban planning. We also conducted participant observation in community meetings related to risk awareness and emergency planning. We analysed relevant policy documents, historical archives, technical and scientific studies, reports of past disasters, and the planning instruments designed and implemented in the aftermath of a landslide disaster. During our fieldwork and document analysis we identified the scale and interrelation of actors to consider both vertical and horizontal arrangements in place. As we show below, our case represents a local-level phenomenon embedded in hierarchical and top-down arrangements that are critically affecting land use policy implementation and its outcomes. Finally, we used official spatial data (Infraestructura de Datos Geoespaciales Chile, n.d.) to map some particularities of the land use.

On May 3rd, 1993, heavy rainfall and high temperatures produced a debris flow or 'alluvium' in the Macul Ravine (Naranjo \& Varela, 1996; Oficina Nacional de Emergencias, 1995). The ensuing floods impacted 28 thousand families in east Santiago, damaged 5,610 housing units, and destroyed 307 (Oficina Nacional de

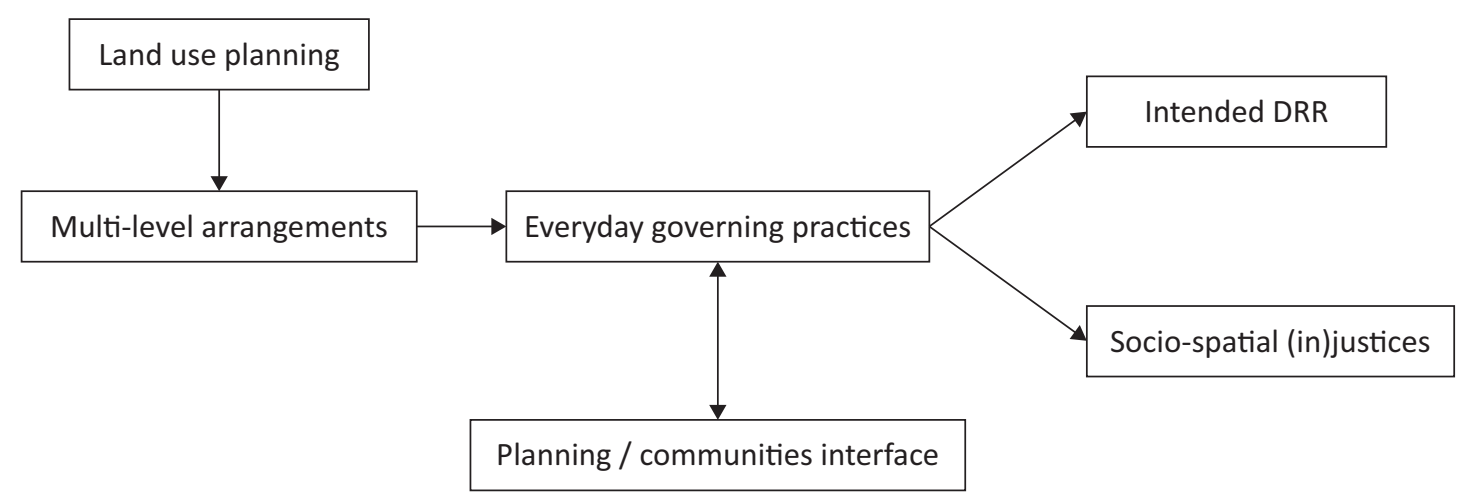

Figure 1. Framework for urban disaster governance. Source: Authors. 


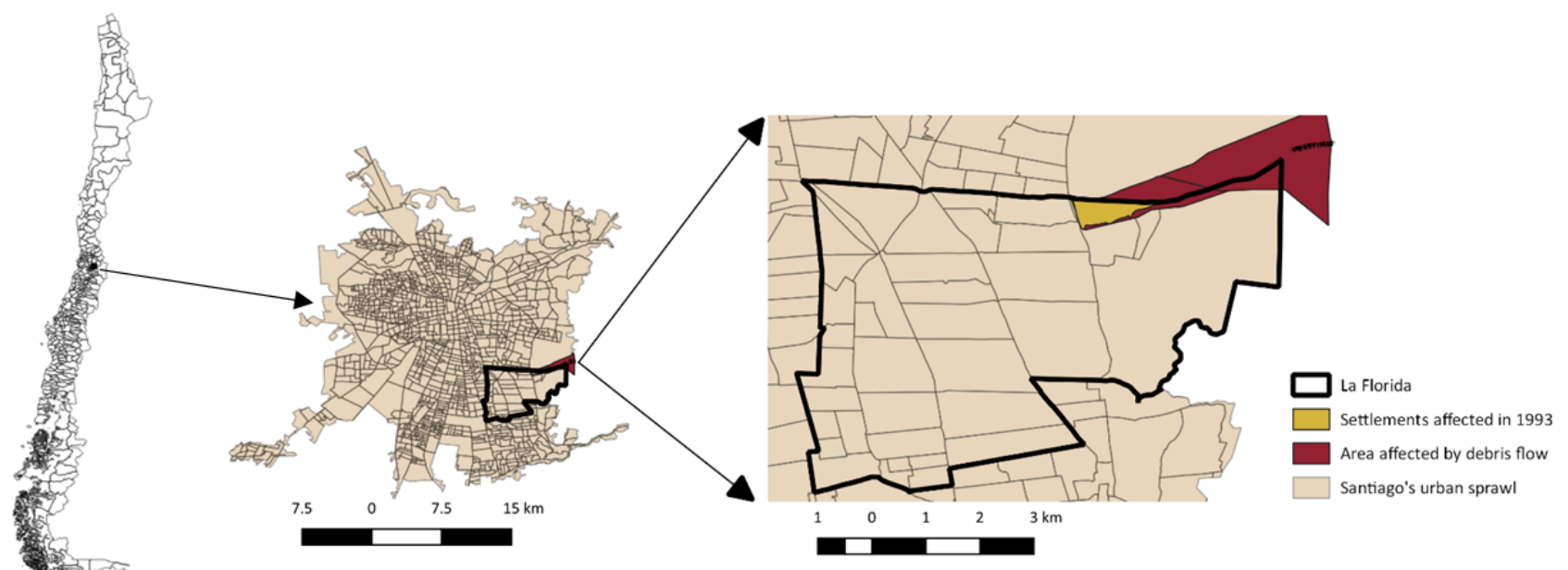

Figure 2. Research area in south-east Santiago, Chile. Source: Authors based on Infraestructura de Datos Geoespaciales Chile (n.d.).

Emergencias, 1995). The most affected households belonged to La Florida, a comuna (Chile's lowest tier territorial division) in south-east Santiago. 23 people died, 8 disappeared, 85 suffered severe injuries, and 3,800 people lost their home. The relief and recovery entailed victim relocation to an emergency camp for almost two years, and subsequently to a newly constructed public housing project called Santa Teresa located near their original dwelling, but in an area protected from the overflows of the Macul Ravine (Secretaría Regional de Vivienda y Urbanismo [SEREMI]-Ministerio de Vivienda y Urbanismo [MINVU], 2013).

For our fieldwork, we focused on the poblaciones (neighbourhoods) of La Higuera and Ampliación La Higuera near the bank of the Macul Ravine, in La Florida. These poblaciones developed through rural migration during the 1960s and 1970s, accessing urban space either through land occupations or via state housing policies (Astaburuaga, 1987; Muñoz, 1990; SEREMI-MINVU, 2013). We also focused on other sites throughout the foothills, where most of the original residents currently live: the Santa Teresa, El Esfuerzo, and Las Perdices neighbourhoods, and visited community centres and the seven mitigation ponds constructed for reducing risks in this area (Ministerio de Obras Públicas, 2006). We contextualised this field research in relation to Chile's institutional development. The country's response to disasters, despite their frequency and magnitude, has been a reactive one (Camus, Arenas, \& Lagos, 2016; Sandoval \& Voss, 2016). This includes the processes of post-disaster recovery as well as more long-term risk management principles, which have tended to be improvised and less planned. In relation to the institutional background of urban planning in Santiago, this emerges from different levels of government. While national laws provide the general institutional framework, regional and local instruments provide the details of land use planning. The latter in- clude the Metropolitan Regulatory Plan (Plan Regulador Metropolitano de Santiago [PRMS]), which aims at developing space in the whole region, comprising 52 comunas (MINVU, 1994). The PRMS defines land uses for the metropolitan area, including areas excluded from development due to natural hazards. On the local level, each comuna should have a Master Regulatory Plan (Plan Regulador Comunal [PRC]), which details land uses within their urban limit. Chile's historical decentralisation process contributes to such urban planning arrangements, which are characterised by strong centralisation, metropolitan fragmentation, and weak capacities in the lower tiers (Consejo Nacional de Desarrollo Urbano, 2017; Garreton, 2017), characteristics that also affect negatively disaster governance (Sandoval \& Voss, 2018).

\section{Results}

\subsection{The Emergence of a Post-Disaster Multi-Level Arrangement}

Following the impacts of the 1993 disaster, the Interior Ministry issued Decree 765 declaring a "Zone affected by the catastrophe" (Ministerio del Interior, 1993). This supported relief and recovery for the victims settled inside it, enabling them to access housing subsidies and relocation procedures to the Santa Teresa village. In 1994, after decades of ignoring Santiago's natural system (Larrain, 1992), a new Metropolitan Plan was approved (MINVU, 1994). This plan included a number of risk zoning regulations that had to be implemented with its formalisation. Among other norms, the PRMS defined areas adjacent to ravines as "Ravine parks" (PRMS Art. 5.2.3.3; MINVU, 1994), where only recreational and other non-permanent activities are allowed; it identified areas susceptible to flood from ravines, where development is restricted or human settlements prohibited (PRMS Art. 8.2.1.1; MINVU, 1994); and introduced sim- 
ilar restrictions in relation to geophysical risks, particularly from landslide hazards (PRMS Art. 8.2.1.4; MINVU, 1994). Given the lack of PRC in the foothills of La Florida, the PRMS mandated that these norms were applied to this new urban space without discussion in the aftermath of the 1993 disaster, first on a temporary basis and then formalised in 2001 with a new PRC. This hierarchical and top-down application of land use norms created a 300,000 square metres zone alongside the Macul Ravine, with a minimum of 100 metres width on each side in which urban development is prohibited or restricted.

Figure 3 shows the restriction zones adopted in the research area associated with the aforementioned restrictions: ravine parks (AV3); flood risks (R-1); and landslide hazards (R-4). The map shows that La Higuera and Ampliación La Higuera are visible as part of the buffer zone. The changed land use transformed these areas by dividing each into a formal section (where uses include residential, commercial, and socio-cultural activities) and an informal section with restricted land use possibilities. Figure 3 also shows that the buffer zone ignores block divisions and streets, running through many residential plots. The exclusion zone affects those residents whose homes fall now in the restricted zones: about 694 people in 99 households. Here we also find two informal campamentos (a type of informal settlement in
Chile), the Santa Luisa and Quebrada de Macul, inhabited by 61 families.

The PRMS has triggered multiple transformations in the foothills, for example expanding Santiago's eastern limit, increasing the urban density of the foothills of The Andes and generating conflicts and environmental mobilisations (Biskupovic, 2015). Regarding the exclusion zone, this area corresponds in part with the zone of the aforementioned Decree 765, thus, where the bulk of the disaster victims were located. However, the rapid and vertical imposition of this arrangement and the buffer zone through a number of governance features practices has impacted the lives of the local people for more than two decades, as detailed in the next subsections.

\subsection{Practices of Implementation: Participation, Enforcement, and Management}

To assess the implementation of this post-disaster land use, we focus on three key governance practices explaining the current state of the buffer zone: voluntary relocation; arbitrary enforcement; and the management of acquired land.

After the 1993 disaster, the housing authorities under the MINVU played an important role, particularly the Service for Housing and Planning (SERVIU), which

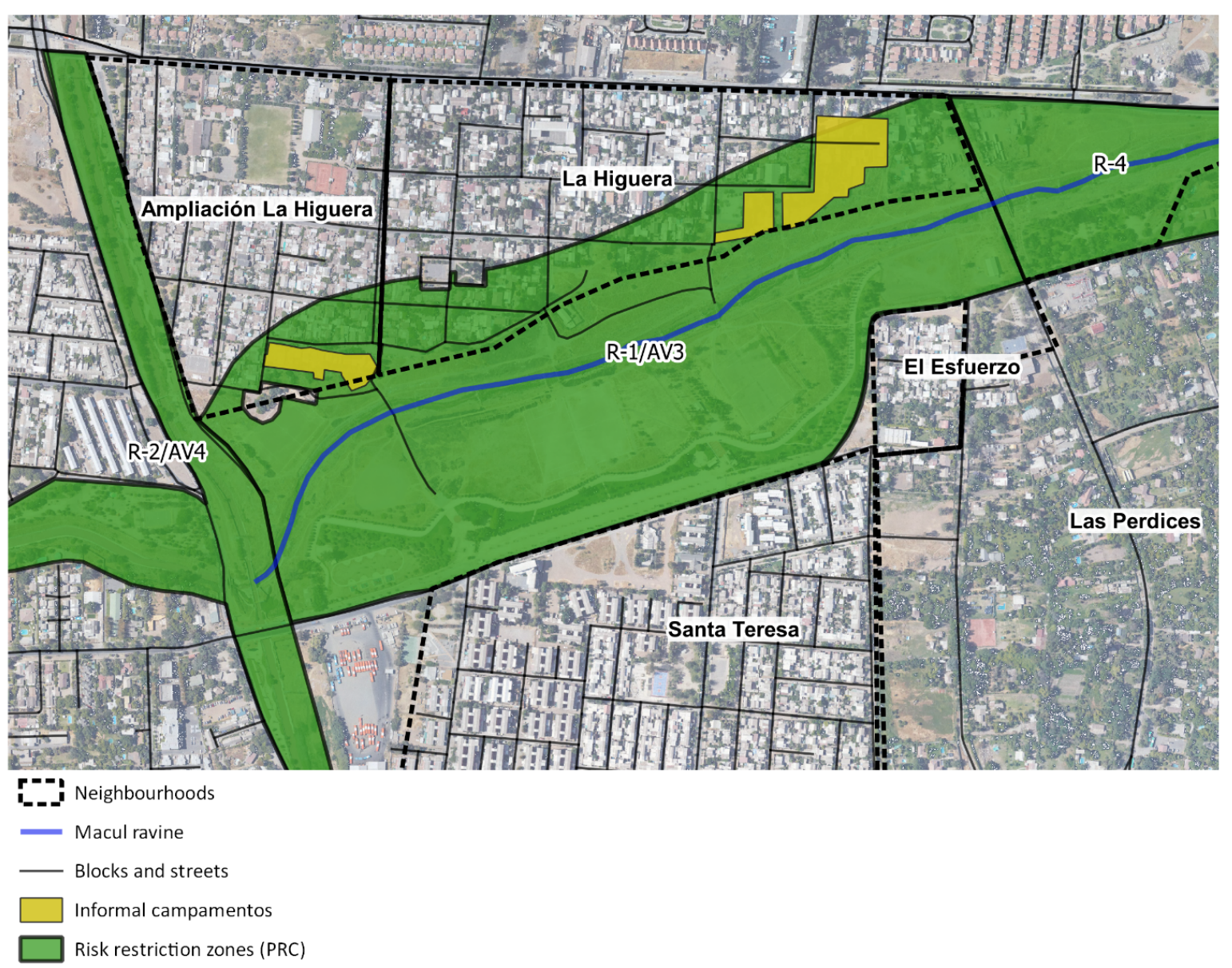

Figure 3. Map showing the risk-related norms in the PRC and the urbanised buffer zone. Source: Authors. 
implements MINVU's plans and policies. SERVIU managed the emergency camp after the disaster and developed the Santa Teresa población for housing disaster victims permanently (Oficina Nacional de Emergencias, 1995; SEREMI-MINVU, 2013). Most people residing in the camp were offered and accepted relocation to Santa Teresa. However, some residents from Ampliación La Higuera and La Higuera returned to their homes after the disaster, as their homes had not been destroyed. Inhabiting a risky area according to Decree 765, interviews reveal that SERVIU developed a "semivoluntary process of negotiation" to relocate them in the new población. Government officials would approach property-owners and offer an exchange between their home and one in Santa Teresa (depending on the value of their home this would be an apartment in a threestorey housing project or a house unit). Many residents accepted this and exchanged property rights. But despite pressure during this negotiation process, some families continued to live in the exclusion zone. The semivoluntariness of the process was thought to push local residents to exchange their properties or lose everything, but as the housing units of many were still standing, they risked remaining there for different reasons. As one interviewee explains: "If I exchange my house and plot from one in Santa Teresa, I leave here all of my memories and experiences....They do not go with me. Everything is here, my people, my neighbours...." For other interviewees, their original living conditions were better than in Santa Teresa, which they saw as a housing project with lower urban standards. Hence, the semi-voluntary process failed to relocate all the people from the buffer zone because of their long-standing attachment and socioeconomic conditions.

A second governance feature refers to the process of defining the buffer zone. To the north of the Macul Ravine bank, the exclusion zone had several demarcations of different sizes between 1994 and 2001. One encompassed the complete neighbourhoods of Ampliación La Higuera and La Higuera (i.e., Decree 765). Another respected the design of streets and plots but was never formalised. The chosen demarcation (Figure 3) measures a minimum of 100 metres from the ravine bank and cuts across several plots. In the South, the line was drawn along the Northern border of Santa Teresa and the exclusion zone was transformed into a public park in 2003. To the east, the line is drawn along the border of the community of El Esfuerzo, which thus remains formal. Nonetheless, between 1994 and 2001, the PRMS applied lines that rendered El Esfuerzo within the exclusion zone. Then, continuous negotiation with state actors and especially connections with a politician with roots in the area resulted in a re-drawing of the line. This informal network is not part of the local or regional levels of government, but resulted directly from access to MINVU at the national scale through this political figure. Local representatives discussed this with housing and planning authorities, who redrew the line in the southern part, despite its hazard exposure. As this politician remembers, "this was done explicitly so that people do not lose their households, [but] they live in an area of high risks...and they know it." This case shows the selective and political enforcement of the norms related to the exclusion zone.

Finally, we discuss land management practices. During the process of relocation, SERVIU was supposed to buy the housing plots inside the buffer zone and transform them according to PRMS restrictions, that is, into recreational spaces. However, while authorities knew that all properties within the exclusion zone should have been acquired and managed, the actual process proved to be difficult in practice. For decades, Chilean State housing structures have been focused on providing an important number of housing units through a targeted and subsidiary model (Cociña, 2018), which has impeded the development of regulatory responsibilities. Thus, the participation of the public sector in land buyouts is ineffective given its institutional capacities and scant resources. As a politician explained: "We tried to transform this [space] into a civic neighbourhood, with a church, a community centre, but the management capacity from the Housing Ministry impeded this kind of project....This would have been the only way to avoid the future squats." As a result of state bureaucracy, a significant area of the buffer zone filled with empty houses and plots became an unmanaged informal space with irregular occupations, entailing some effects that we unpack now.

\subsection{The Just and Unjust Effects of the Land Use}

The land use plan has produced some positive outcomes. It organises spatial development while protecting thousands of people living in formally defined 'safe' areas from natural hazards. This is recognised by the victims of the 1993 disaster settled in Santa Teresa. However, they still suffer from a post-disaster recovery process linked to neoliberal housing policies, which resulted in relocation to segregated, densely populated areas that lack basic urban services (Rodríguez \& Sugranyes, 2004), features acknowledged throughout the foothills. The Santa Teresa is an example of what has been described as the 'dark side' of Chile's neoliberal housing policies: Whereas the aggregated housing deficit has diminished with these policies, they have done so by increasing socio-spatial segregation and generating highly insecure, violent, and deteriorated spaces for lower income groups (Ducci, 1997). Along with this trend experienced by the relocated debris flow victims, the multi-level arrangement and the buffer zone generated have (re)produced spatial injustices for the communities settled there. Based on the issues identified by residents of the buffer zone, we have focused on those that are further marginalising them as a community and affecting their local resilience. We categorised these and expand on three issues: urban exclusion; spatial deterioration; and disaster risks reproduction. 


\subsubsection{Urban Exclusion}

With relocation, abandoned houses and plots unmanaged by SERVIU were sometimes squatted by the original owners who, after receiving a unit in Santa Teresa, rented that unit out, or by people from the exclusion zone itself as a means to enlarge their plot, locally referred to as micro-squatting. Although these squatters are officially subject to eviction, such practices also address over-crowding problems. Many squatters are from the neighbourhood itself or come from nearby areas, arriving from other informal spaces around the foothills aiming for more permanent dwelling. Therefore, this space has produced an irregular rental housing market for vulnerable groups seeking households, such as international migrants (especially Peruvians). The 2017 Census shows that while immigrants represent $6 \%$ of the people living formally in La Higuera, they are $12 \%$ of the inhabitants of the exclusion zone. Also, they tend to be younger than in their formal counterpart, being particularly economically active groups. Although not necessarily illegal, international immigrants are generally more likely to suffer from structural problems related to housing (Fundación Vivienda, 2018). These rental spaces are precarious, with poor quality housing (e.g., mediaguas), illegal connections to water and electricity services, and lack of tenure security. Such irregular spatial practices are logical in Santiago given its structural lack of access to decent and affordable housing, especially when public policies are associated with segregation, overcrowding, and low quality for low income groups (Fundación Vivienda, 2018; Rodríguez \& Sugranyes, 2004). The buffer zone provides respite from over-crowding but reproduces exclusionary development processes that arises from inadequate state policies and the decisions of vulnerable groups given their limited choices.

\subsubsection{Spatial Deterioration}

The buffer zone is spatially deteriorating in public places, particularly along the bank of the Macul Ravine. Unlike the southern part where a green public park was built with regional-level funding, the northern exclusion zone is deserted and undeveloped, and used for crime, drugdealing, and drug-use, increasing local insecurities (see Figure $4 \mathrm{a}$ and $4 \mathrm{~b}$ ). While owned by the municipality, it reportedly lacks funds for managing and transforming this public area. But there is also uneven funding for services such as streets or sidewalk pavements (see Figure $4 \mathrm{c}$ and 4d), or for addressing the current termite infestation, as residents of the exclusion zone cannot apply for public subsidies. Thus, households also experience spatial deterioration as residents are unwilling to invest in their properties given their irregular status, as a potential sale value would be only the fiscal value, roughly $59 \%$ of the market price (Ruiz-Tagle, Labbé, Rocco, Schuster, \& Muñoz, 2018). As a resident explains: "We are frozen, we cannot apply to these public funds for improving our houses...[and] the termites are the cancer of wood." A 75-year-old resident says she cannot access credit and that her "beautiful house is falling little by little." As a result, properties inside the exclusion zone have devaluated, making owners poorer, despite long-term ownership.

\subsubsection{Disaster Risk Reproduction}

Many informants and official documents argue that constructing seven mitigation ponds, roughly two kilometres upstream from the buffer zone, has reduced the likely impact of an event similar to the 1993 disaster (Sepúlveda et al., 2006; SEREMI-MINVU \& INDUAMERICANA, 2014). These ponds need maintenance and systematic cleaning. However, a persistent ambivalence towards managing risks persists in the area in relation to the Macul Ravine and other ignored ravines (Ferrando, Sarricolea, \& Pliscoff, 2014; Fuentealba \& Verrest, 2020; Garrido \& Sepúlveda, 2012; SEREMI-MINVU \& INDUAMERICANA, 2014). Such risks are borne by the informal community in the buffer zone. Living in an informal settlement means not only that they might face greater uncertainties in the event of another disaster, but also that they inhabit a space that all acknowledge as hazardous. As a resident describes: "What happens tomorrow...if there is a new alluvium? Those people will not have any housing solution because they were settled in a prohibited place." Another resident points out that their choice to live here limits their ability to demand permanent risk reduction. 'Voluntarily' living in the exclusion zone has in practice made this community invisible to disaster planning initiatives, reproducing their disaster vulnerability.

After an alluvium in March 2015 in northern Chile, an opportunity for addressing problems in the exclusion zone emerged. Then, some discussions took place at the national level (e.g., Biblioteca del Congreso Nacional de Chile, 2015) and relevant public organizations and the community met in the foothills to discuss, inter alia, three relevant topics for the buffer zone. First, the need to address irregular occupation of SERVIU owned plots, which led SERVIU to update the registry of these, including those belonging to private owners ( $n=98$ ), those it had acquired ( $n=93$ ), and those it needed to acquire $(n=41)$. Second, while some efforts at improving disaster response in the buffer zone were made, these were limited to emergency preparedness and evacuation routes. Regardless, informants state that bureaucratic obstacles impeded the realisation of massive evacuation try-outs. Finally, following a participatory process in 2017, it was decided that the abandoned public space north of the ravine should be transformed into a new green public park, with a design to be developed in 2020. However, even though the residents of the exclusion zone gained some visibility, there has not been any substantive change in their situation. From their perspective, the land use initiative has condemned them to live in uncertainty regarding both spatial injustices and possible climate disasters. 


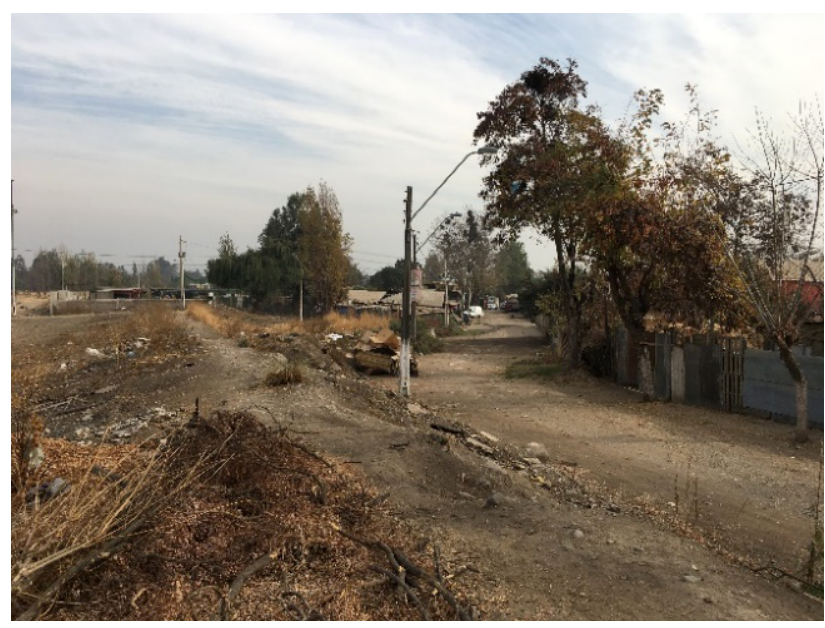

(a)

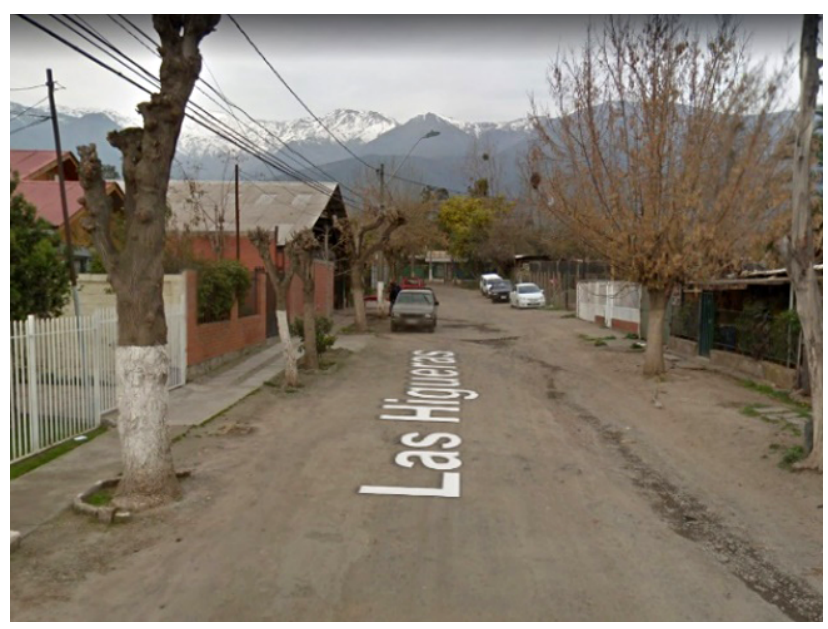

(c)

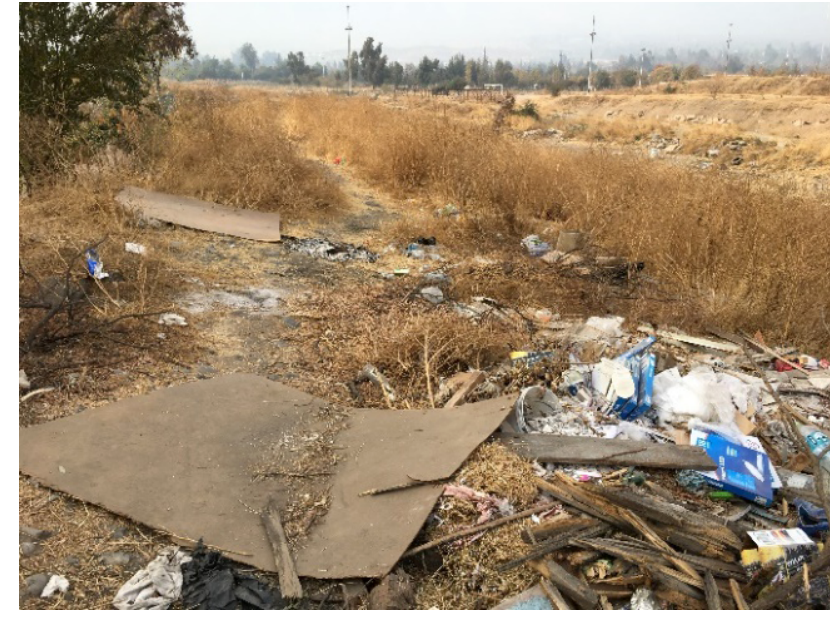

(b)

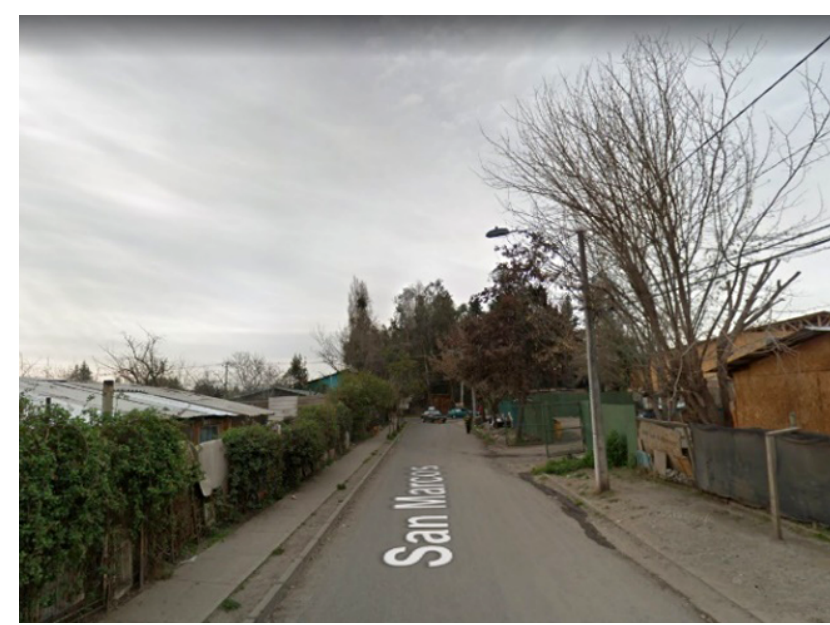

(d)

Figure 4. Deteriorating spaces in the buffer zone. Source: Authors' archive from May 2018 (Figures 4a and 4b) and Google Street View from August 2015 (Figures 4c and 4d).

\section{Discussion and Conclusion}

Our article expanded the knowledge on urban disaster governance by addressing the relationship between DRR, urban politics, and spatial (in)justices. By grounding governance in situated practices, we showed that despite well-intentioned initiatives defining risk areas being implemented, they reproduce and even create new injustices. While a land use plan can protect a population by defining a buffer zone that restricts development, it can adversely include those who relocate to worse housing situations or stay informally within the buffer zone. The planning process of excluding land from urban development also furthered socio-spatial exclusion of local communities. Addressing the challenges of the poor and marginalised needs resources and political will. But in particular, three governance conditions need to be considered in DRR and urban planning.

First, as post-disaster settings are highly contentious moments, decisions taken rapidly will affect concerned people in the short and long-term. However, in such rapid decision-making, there is little space for addressing contestations, creating depoliticised environments where no discussions of the root causes of risks are addressed. The Santiago case shows how affected groups see their participation in risk management processes reduced (as in the Santa Teresa housing recovery) or excluded (as in structural disaster responses like the mitigation ponds or the exclusion zone). Not only are local knowledge, choices, and experiences excluded in some risk management processes, but interventions themselves may produce adverse and detrimental consequences such as within the informalised community. Hence, the depoliticization of post-disaster settings means a lack of power and participation of local communities, which implies that planning interventions should consider their long-term consequences and address structural causes of uneven disaster risks.

Second, inconsistent enforcement of interventions may produce unjust situations. The voluntariness of relocation during the exclusion zone's definition and the lack of enforcement of the ban on building in the exclu- 
sion zone has led to households in risky areas experiencing economic hardship. Although the El Esfuerzo community managed to move the border of the exclusion zone and thus lives formally, it is at risk from future floods and landslides. From a DRR perspective, this shows how grounded risk management can be both spatially unjust and ineffective, even rendering useless the dichotomous definition of formal and informal. This mirrors Yiftachel's (2009) grey spaces in that defining certain categories becomes blurry, particularly by naming spaces as formal/secure and informal/at risk. It also raises questions about whether governance interventions should aim at making spatial areas less vulnerable or people less vulnerable, and how to address the dilemma where people either comply to voluntary relocations or through their own choices face further marginalisation.

Finally, governance actors have uneven capacities. We described how transferring norms and regulations from one level of government to another does not consider problems associated with managing urban space at the local level. This is consistent with previous evidence of disaster governance in Chile in relation to hierarchical and top-down inter-relations between scales of government, as Sandoval and Voss (2018) argue in a recent postdisaster context. In that sense, our analysis adds an additional dimension by describing how governance arrangements extend over time, maintaining some unjust effects on the ground. This includes the bureaucratic complexity and resource shortage in managing empty houses and plots and developing abandoned spaces. Hence, the buffer zone problems reflect low capacity and resources at local level and the political lack of will at higher levels to reduce the vulnerability of people by using an appeasement strategy of pacification. For sustainable, inclusive, and resilient cities, the focus must be on the daily practices and challenges of disaster governance and on empowering governance actors at the lowest level to structurally address the long-term challenges for better risk reduction and spatial justice.

\section{Acknowledgments}

We thank two anonymous reviewers for their comments on an early draft. This article has been financially supported by the Becas Chile Doctoral Program Scholarship \#72170272 from the Government of Chile and the Governance and Inclusive Development Group of the Amsterdam Institute for Social Science Research of the University of Amsterdam.

\section{Conflict of Interests}

The authors declare no conflict of interests.

\section{References}

Ahrens, J., \& Rudolph, P. M. (2006). The importance of governance in risk reduction and disaster manage- ment. Journal of Contingencies and Crisis Management, 14(4), 207-220.

Alvarez, M. K., \& Cardenas, K. (2019). Evicting slums, 'building back better': Resiliency revanchism and disaster risk management in Manila. International Journal of Urban and Regional Research, 43(2), 227-249. http://doi.org/10.1111/1468-2427.12757

Anguelovski, I., Shi, L., Chu, E., Gallagher, D., Goh, K., Lamb, Z., . . . Teicher, H. (2016). Equity impacts of urban land use planning for climate adaptation: Critical perspectives from the Global North and South. Journal of Planning Education and Research, 36(3), 333-348. http://doi.org/10.1177/ 0739456X16645166

Asian Development Bank. (2016). Reducing disaster risk by managing urban land use: Guidance notes for planners. Mandaluyong: Asian Development Bank.

Astaburuaga, P. (1987). Campamento Ampliación La Higuera [Ampliación La Higuera camp]. In E. Walker, M. Saborido, C. Tardito, P. Astaburuaga, \& X. Valdés (Eds.), Planificación desde la comunidad: Ampliando el campo de lo posible [Planning from the community: Widening the field of what is possible] (pp. 117-140). Santiago: CIPMA.

Bevir, M. (2013). A theory of governance. Los Angeles, CA, and Berkeley, CA: University of California Press.

Biblioteca del Congreso Nacional de Chile. (2015). Zonas de riesgo en la Quebrada de Macul, comuna de La Florida [Risk zones in the Macul Ravine, La Florida comuna]. Santiago: Biblioteca del Congreso Nacional de Chile.

Biskupovic, C. (2015). From rural haven to civil political project: Utopian ideals and environmental protection in the precordillera, Santiago, Chile. Journal of Political Ecology, 22, 183-198.

Burby, R. J. (1998). Cooperating with nature: Confronting natural hazards with land-use planning for sustainable communities. Washington, DC: Joseph Henry Press. http://doi.org/10.17226/5785

Burby, R. J., Deyle, R. E., Godschalk, D. R., \& Olshansky, R. B. (2000). Creating hazard resilient communities through land-use planning. Natural Hazards Review, 1(2), 99-106.

Camus, P., Arenas, F., \& Lagos, M. (2016). Visión histórica de la respuesta a las amenazas naturales en Chile y oportunidades de gestión del riesgo de desastre [Historical overview of natural hazards response in Chile and opportunities for disaster risk management]. Revista de Geografia Norte Grande, 46, 9-20.

Castán Broto, V. (2017). Urban governance and the politics of climate change. World Development, 93, 1-15. http://doi.org/10.1016/j.worlddev.2016.12.031

Cociña, C. (2018). Urban universalism: The housing debt in the context of targeted policies. In J. F. VergaraPerucich \& C. Boano (Eds.), Neoliberalism and urban development: The case of Santiago (pp. 71-82). London and New York, NY: Routledge.

Consejo Nacional de Desarrollo Urbano. (2017). Propues- 
tas para una nueva institucionalidad para la gobernanza urbana [Proposals for a new institutionality for urban governance]. Santiago: Consejo Nacional de Desarrollo Urbano and United Nations Development Programme.

Cornea, N. L., Véron, R., \& Zimmer, A. (2017). Everyday governance and urban environments: Towards a more interdisciplinary urban political ecology. Geography Compass, 11(4), e12310. http://doi.org/ 10.1111/gec3.12310

Di Baldassarre, G., Kemerink, J. S., Kooy, M., \& Brandimarte, L. (2014). Floods and societies: The spatial distribution of water-related disaster risk and its dynamics. Wiley Interdisciplinary Reviews: Water, 1(2), 133-139. http://doi.org/10.1002/wat2.1015

Douglass, M., \& Miller, M. A. (2018). Disaster justice in Asia's urbanising anthropocene. Environment and Planning E: Nature and Space, 1(3), 271-287.

Ducci, M. E. (1997). Chile: El lado obscuro de una política de vivienda exitosa [Chile: The dark side of a successful housing policy]. Eure, 23(69), 99-115.

Ferguson, J. (1994). The anti-politics machine: "Development," depoliticization, and bureaucratic power in Lesotho. Minneapolis, MN: University of Minnesota Press.

Ferrando, F., Sarricolea, P., \& Pliscoff, P. (2014). Determinación de amenazas y análisis de riesgo del sector precordillerano de la comuna de La Florida [Determination of hazards and risk analysis of the foothills area of La Florida comuna]. Santiago: Municipality of La Florida.

Fuentealba, R., \& Verrest, H. (2020). Disrupting risk governance? A post-disaster politics of inclusion in the urban margins. Urban Planning, 5(3), 274-287.

Fundación Vivienda. (2018). Déficit habitacional cuantitativo, Censo 2017 [Quantitative housing deficit, 2017 Census]. Santiago: Fundación Vivienda.

Gall, M., Cutter, S. L., \& Nguyen, K. (2014). Governance in disaster risk management (IRDR AIRDR Publication No. 3). Beijing: Integrated Research on Disaster Risk.

Garreton, M. (2017). City profile: Actually existing neoliberalism in Greater Santiago. Cities, 65, 32-50. http:// doi.org/10.1016/j.cities.2017.02.005

Garrido, N., \& Sepúlveda, S. (2012). Peligro de flujos de detritos en Quebrada de Macul, Región Metropolitana y propuestas de medidas de mitigación [Debris flow hazard in the Macul Ravine, Metropolitan Region, and proposal of mitigation measures]. In Actas XIII Congreso Geológico Chileno 13 [Proceedings of the XIII Chilean Geological Congress] (pp. 1015-1017). Antofagasta: Sociedad Geológica de Chile.

Godschalk, D. R. (2003). Urban hazard mitigation: Creating resilient cities. Natural Hazards Review, 4(3), 136-143. http://doi.org/10.1061/(ASCE)15276988(2003)4:3(136)

Gupta, J., Verrest, H., \& Jaffe, R. (2015). Theorizing governance. In J. Gupta, K. Pfeffer, H. Verrest, \& M. Ros-
Tonen (Eds.), Geographies of urban governance: Advanced theories, methods and practices (pp. 27-44). New York, NY: Springer. http://doi.org/10.1007/9783-319-21272-2

Harvey, D. (1973). Social justice and the city. Oxford: Basil Blackwell.

Huang, S. (2018). Understanding disaster (in)justice: Spatializing the production of vulnerabilities of indigenous people in Taiwan. Environment and Planning E: Nature and Space, 1(3), 382-403. http://doi.org/ $10.1177 / 2514848618773748$

Infraestructura de Datos Geoespaciales Chile. (n.d.). Homepage. Infraestructura de Datos Geoespaciales Chile. Retrieved from http://www.ide.cl

Ingram, J. C., Franco, G., Rio, C. R. del., \& Khazai, B. (2006). Post-disaster recovery dilemmas: Challenges in balancing short-term and long-term needs for vulnerability reduction. Environmental Science and Policy, 9(7/8), 607-613. http://doi.org/10.1016/j.envsci. 2006.07.006

Koster, M., \& Nuijten, M. (2016). Coproducing urban space: Rethinking the formal/informal dichotomy. Singapore Journal of Tropical Geography, 37(3), 282-294. http://doi.org/10.1111/sjtg.12160

Larrain, P. (1992). El sistema natural en la planificación urbana chilena [The natural system in Chilean urban planning]. Revista de Geografia Norte Grande, 19, 59-68.

Marks, D. (2015). The urban political ecology of the 2011 floods in Bangkok: The creation of uneven vulnerabilities. Pacific Affairs, 88(3), 623-651. http://doi.org/ $10.5509 / 2015883623$

Marks, D., \& Lebel, L. (2016). Disaster governance and the scalar politics of incomplete decentralization: Fragmented and contested responses to the 2011 floods in Central Thailand. Habitat International, 52, 57-66. http://doi.org/10.1016/j.habitatint.2015. 08.024

McFarlane, C. (2012). Rethinking informality: Politics, crisis, and the city. Planning Theory and Practice, 13(1), 89-108. http://doi.org/10.1080/14649357. 2012.649951

Miller, M. A., \& Douglass, M. (2016). Disaster governance in urbanising Asia. Singapore: Springer. http://doi. org/10.1007/978-981-287-649-2

Ministerio de Obras Públicas. (2006). Catastro de obras en cauces naturales y areas de restricción. Vol II.2. Etapa II: Catastros de obras menores en cauces naturales del Gran Santiago [Registry of works in natural water courses and restriction areas. Vol II.2. Stage II: Registry of minor works in natural water courses of the Greater Santiago]. Santiago: Ministerio de Obras Públicas.

Ministerio de Vivienda y Urbanismo. (1994). Plan regulador metropolitano de Santiago 1994 [Metropolitan regulatory plan of Santiago 1994]. Santiago: Ministerio de Vivienda y Urbanismo.

Ministerio del Interior. (1993). Decreto 765, 16-06-1993: 
Señala como zona afectada por catástrofe sector geográfico de comuna que indica [Decree 765, 16-06-1993: Declares a zone affected by catastrophe the geographical area from the indicated comuna]. Santiago: Biblioteca del Congreso Nacional de Chile.

Muñoz, O. (1990). Quebrada de Maul: Un factor de desequilibrio físico en la comuna de La Florida [Macul Ravine: A factor of physical imbalance in the La Florida comuna]. Revista Geográfica de Chile: Terra Australis, 32, 103-134.

Naranjo, J., \& Varela, J. (1996). Flujos de detritos y barros que afectaron el sector oriente de Santiago el 3 de mayo de 1993 [Debris and mudflows that affected the eastern area of Santiago on the 3 of May 1993] (Boletín Del Servicio Nacional de Geología y Minería No. 47). Santiago: Servicio Nacional de Geología y Minería.

Nygren, A. (2018). Inequality and interconnectivity: Urban spaces of justice in Mexico. Geoforum, 89, 145-154. http://doi.org/10.1016/j.geoforum.2017. 06.015

Oficina Nacional de Emergencias. (1995). Serie estudio de caso: Aluvión de la Florida ocurrido el 3 de mayo de 1993 [Case study series: La Florida alluvium of 3 of May 1993]. Santiago: Oficina Nacional de Emergencias.

Oliver-Smith, A., Alcántara-Ayala, I., Burton, I., \& Lavell, A. (2017). The social construction of disaster risk: Seeking root causes. International Journal of Disaster Risk Reduction, 22, 469-474. http://doi.org/ 10.1016/j.ijdrr.2016.10.006

Parthasarathy, D. (2015). Informality, resilience, and the political implications of disaster governance. Pacific Affairs, 88(3), 551-575.

Pelling, M. (2011). Urban governance and disaster risk reduction in the Caribbean: The experiences of Oxfam GB. Environment and Urbanization, 23(2), 383-400. http://doi.org/10.1177/0956247811410012

Pelling, M., \& Dill, K. (2010). Disaster politics: Tipping points for change in the adaptation of sociopolitical regimes. Progress in Human Geography, 34(1), 21-37. http://doi.org/10.1177/0309132509105004

Raju, E., \& da Costa, K. (2018). Governance in the Sendai: A way ahead? Disaster Prevention and Management: An International Journal, 27(3), 278-291. http://doi. org/10.1108/DPM-08-2017-0190

Rodríguez, A., \& Sugranyes, A. (2004). El problema de vivienda de los "con techo" [The housing problem of those "with roof"]. Eure, 30(91), 53-65. http:// doi.org/10.1017/CBO9781107415324.004

Roy, A. (2005). Urban informality: Toward an epistemology of planning. Journal of the American Planning Association, 71(2), 147-158. http://doi.org/10.1080/ 01944360508976689

Ruiz-Tagle, J., Labbé, G., Rocco, V., Schuster, J. P., \& Muñoz, J. C. (2018). Recuperación de plusvalías para financiar la inserción de viviendas sociales en barrios consolidados [Recovering surplus value for funding the insertion of social housing in consolidated neighbourhoods]. Santiago: Centro de Políticas Públicas UC.

Rumbach, A. (2016). Decentralization and small cities: Towards more effective urban disaster governance? Habitat International, 52, 35-42. http://doi.org/ 10.1016/j.habitatint.2015.08.026

Rumbach, A. (2017). At the roots of urban disasters: Planning and uneven geographies of risk in Kolkata, India. Journal of Urban Affairs, 39(6), 783-799. http:// doi.org/10.1080/07352166.2017.1282771

Sandoval, V., \& Voss, M. (2016). Disaster governance and vulnerability: The case of Chile. Politics and Governance, 4(4), 107-116. http://doi.org/10.4324/ 9781315463896

Sandoval, V., \& Voss, M. (2018). Multi-scalar disaster governance and vulnerability in Chile. In G. Forino, S. Bonati, \& L. M. Calandra (Eds.), Governance of risk, hazards and disasters: Trends in theory and practice (pp. 27-42). Abingdon and New York, NY: Routledge.

Sandoval, V., Gonzalez-Muzzio, C., \& Albornoz, C. (2017). Post-disaster institutional and community responses: Uneven outcomes on environmental justice and resilience in Chaitén, Chile. In A. Allen, L. Griffin, \& C. Johnson (Eds.), Environmental justice and urban resilience in the Global South (pp. 79-94). New York, NY: Palgrave Macmillan.

Secretaría Regional de Vivienda y Urbanismo-Ministerio de Vivienda y Urbanismo. (2013). Reconstruyendo mi barrio, Villa Santa Teresa. Recuperando la historia y la identidad de un barrio afectado por una catástrofe natural [Reconstructing my neighbourhood, Santa Teresa Village. Recovering the history and identity of a neighbourhood affeted by a natural catastrophe]. Santiago: Secretaría Regional de Vivienda y Urbanismo and Ministerio de Vivienda y Urbanismo.

Secretaría Regional de Vivienda y Urbanismo-Ministerio de Vivienda y Urbanismo, \& INDUAMERICANA. (2014). Estudio "Análisis áreas riesgo precordillera Vitacura y La Florida." Sub etapa 4.1 Diagnóstico y conclusiones [Study "Analysis of risk areas in the foothills of Vitacura and La Florida." Sub stage 4.1 Diagnostics and conclusions]. Santiago: Ministerio de Vivienda y Urbanismo.

Sepúlveda, S. A., Rebolledo, S., \& Vargas, G. (2006). Recent catastrophic debris flows in Chile: Geological hazard, climatic relationships and human response. Quaternary International, 158(1), 83-95. http://doi. org/10.1016/j.quaint.2006.05.031

Soja, E. W. (2010). Seeking spatial justice. London and Minneapolis, MN: University of Minnesota Press.

Srikandini, A. G., van Voorst, R., \& Hilhorst, D. (2018). Disaster risk governance in Indonesia and Myanmar: The practice of co-governance. Politics and Governance, 6(3), 180-189. http://doi.org/10.17645/pag. v6i3.1598

Susman, P., O’Keefe, P., \& Wisner, B. (1983). Global disasters, a radical interpretation. In K. Hewitt (Ed.), Inter- 
pretations of calamity: From the viewpoint of human ecology (pp. 263-283). Boston, MA: Allen \& Unwin.

Swyngedouw, E. (2005). Governance innovation and the citizen: The Janus face of governance-beyond-thestate. Urban Studies, 42(11), 1991-2006. http://doi. org/10.1080/00420980500279869

Tierney, K. (2012). Disaster governance: Social, political, and economic dimensions. Annual Review of Environment and Resources, 37(1), 341-363. http://doi.org/ 10.1146/annurev-environ-020911-095618

Torfing, J., Peters, B. G., Pierre, J., \& Sorensen, E. (2012). Interactive governance: Advancing the paradigm. New York, NY: Oxford University Press. http://doi. org/10.1093/acprof:oso/9780199596751.001.0001

United Nations Office for Disaster Risk Reduction. (2020). Terminology on disaster risk reduction. United $\mathrm{Na}$ tions Office for Disaster Risk Reduction. Retrieved from https://www.undrr.org/terminology

Wacquant, L. (2015). Class, ethnicity, and state in the making of marginality: Revisiting territory of urban relegation. In A. Roy \& E. S. Crane (Eds.), Territories of poverty: Rethinking North and South (pp. 247-259). London and Athens, GA: The University of Georgia Press.

Wamsler, C. (2006). Mainstreaming risk reduction in urban planning and housing: A challenge for international aid organisations. Disasters, 30(2), 151-177. http://doi.org/10.1111/j.0361-3666.2006.00313.x

Weinstein, L., Rumbach, A., \& Sinha, S. (2019). Resilient growth: Fantasy plans and unplanned developments in India's flood-prone coastal cities. International Journal of Urban and Regional Research, 43(2), 273-291. http://doi.org/10.1111/1468-2427.12743

Wisner, B., Blaikie, P., Cannon, T., \& Davis, I. (2004). At risk: Natural hazards, people's vulnerability and disasters. London: Routledge.

Yiftachel, O. (2009). Critical theory and "gray space": Mobilization of the colonized. City, 13(2/3), 246-263. http://doi.org/10.1080/13604810902982227

\section{About the Authors}

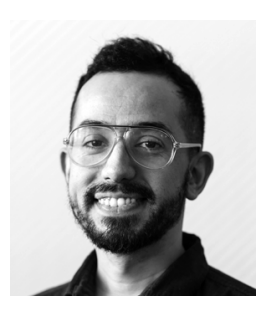

Ricardo Fuentealba is a PhD Candidate at the Governance and Inclusive Development Programme Group of the AISSR of the University of Amsterdam. His doctoral research centres on understanding how post-disaster recovery and reconstruction processes are transforming urban contexts in relation to future risks. He holds an MSc in Human Geography from the University of Bristol. Having experience in the Chilean Public Sector and in Latin American NGOs, he has published on environmental politics, regional and local development, urban culture, and indigenous development policy.

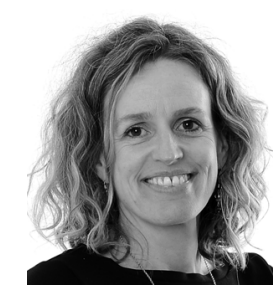

Hebe Verrest is Associate Professor in International Development Studies at the University of Amsterdam. Having a background in Human Geography, she has a key interest in spatial dimensions of development issues, in particular those related to urbanization and cities. Leading in her work is a focus on exclusion and inequality. These themes come back in more specific topics that she works on such as climate adaptation, urban governance, urban flooding, smart cities, and entrepreneurship. Geographically, her expertise is in small and medium cities in The Caribbean, and increasingly on coastal cities in South Asia.

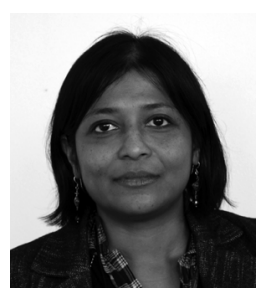

Joyeeta Gupta is Faculty Professor on Sustainability and Professor of Environment and Development in the Global South at the AISSR of the University of Amsterdam and IHE Delft Institute for Water Education in Delft. She leads the Programme Group on Governance and Inclusive Development. She was Co-Chair of UNEP's Global Environment Outlook-6 (2016-2019), published by Cambridge University Press, presented to governments participating in the United Nations Environment Assembly in 2019, and which won the Association of American Publishers PROSE Award for Environmental Science. She has also just been named as Co-Chair of the Earth Commission (2019-2021), set up by Future Earth, together with Johan Rockström and Dahe Qin. 